\title{
Artigo
}

\section{Brazil's Rise on the International Scene: Brazil and the World}

\author{
A ascensão do Brasil no cenário internacional: \\ o Brasil e o mundo
}

AMADO LUIZ CERVO*

Rev. Bras. Polit. Int. 53 (special edition): 7-32 [2010]

\section{From the Cardoso to the Lula era: Brazil and the world}

In the course of their sixteen years in office, Presidents Fernando Henrique Cardoso (1995-2002) and Luiz Inácio Lula da Silva (2003-2010) were two statesmen who defined the pattern of Brazil's integration into the international scene at the turn from the $20^{\text {th }}$ into the $21^{\text {st }}$ century. Cardoso's ideas and decisions drew inspiration from the neoliberal political philosophy, while Lula's derived from a logistic mission of the State. The two presidents' modes of thinking are not sufficient to explain their strategies, though. As he essayed the logistic model of foreign policy in his second term, Cardoso, the neoliberal turned skeptical when he formulated the concept of asymmetrical globalization, paved the way for his successor, who adopted the new model to promote Brazil's interdependent integration into the international scene.

\section{From neoliberalism to global interdependence}

Neoliberalism had both adverse and positive effects on Brazil's international relations. Adverse effects included unilateral opening of the domestic consumers market, foreign trade deficit, foreign indebtedness, sale of assets of Brazilian companies, submission to consensuses and advice from capitalism's center, obedience to the rules of global governance established by the rich to their own benefit, and the sacrificing of relations with emerging countries in favor of the first world; in sum, a country's loss of power on the international scene.

In time, though, economic opening resulted in the modernization of industrial plants and made the Brazilian economy more competitive, while

\footnotetext{
* Tenured Emeritus Professor of History of International Relations of University of Brasilia - UnB and senior researcher of National Council for Scientific and Technological Development - CNPq (alcervo@unb.br).
} 
liberalism led to a smaller role of the State and the attendant rise of society. Lula boarded this train already on the move and advanced farther on the path of real interdependence. He discarded previous mechanisms of dependent integration and placed Brazil among the nations that move on their own feet in search of their destiny, with their governments' support. Here lies the jump in quality of the Brazilian model of integration into the international scene at the turn of the millennium: the State's intermediary role and external action on behalf of the social segments, subsuming the national interest, which encompasses the objectives of producers and consumers, entrepreneurs and wage earners alike.

To stake out its space in the world, instead of just opening itself to the world as before, Brazil would have to face up the asymmetries caused by the inequality of power and benefits in the international order. To what extent has Lula's Brazil succeeded in this respect?

The international order at the outset of the new millennium is in a state of effervescence involving actors and powers. Neoliberalism has receded to the periphery and placed itself at the service of the European Union and the United States, which reinforced their political, geopolitical, and economic alliance and resisted the regulation of economic activities, the root of the 2008/09 crisis. On the other hand, globalization had altered an order imposed by the liberal doctrine for the order dominated by the States and its military power, and by transnational corporations. Old capitalism's supremacy and global logistic have had to come face to face with the emerging nations, which have come together to tame globalization's impetus. To the north, one sees what Bertrand Badie calls the power's impotence; to the south, we see the counterpower's play; and according to Gilberto Dupas, both actors recognize the limits of the national States.

In the south, counterpower springs from the social and political legitimization on whose bases the rules of the new order are to be defined so as to benefit all; it springs further from democracy, which leads to the formulation of these rules. It springs also from neoliberalism, which motivates individuals and, on the other extreme, from terrorism, which nourishes the root causes. Globalization's order is entering a new, still more global phase: each actor feels bound to the whole - to the rich and to the poor, to the developed and to the emerging countries, and to those benefited or excluded by capitalism - since all are affected by international trade, peace and war, the environment, human rights, the energy and the financial crises, and the scarcity of food. The entry of new actors on the stage adds other voices to the criticism of global asymmetries, and hampers diplomatic negotiations. This explains the stagnation of multilateralism, which was supposed to draw up the rules for the global order in the $21^{\text {st }}$ century; it also explains the defensive reaction on the part of the developed countries, which reactivated the G-8, as well as the confrontation of two dispute settlement strategies: the Chinese-Brazilian, through the peaceful means of diplomatic negotiations, and the US-NATO, through the violent means of intervention or sanction. 
Since Cardoso and during Lula's Administration, international order has undergone significant changes. These changes have allowed Brazilian foreign policy to mitigate the internal effects of the order established by others and, at the same time, to become an active participant in the formulation of the new order. How has this occurred?

With globalization of democracy seeming a utopian objective, as shown by the American failure in Iraq and by the continuity of the Chinese political regime, why not democratize globalization? This objective, susceptible of producing real, positive effects, is the mainspring of Brazilian foreign policy.

As a first step, Lula's foreign diplomacy adopted this approach at the World Trade Organization's Conference in Cancún, in 2003. Since World War II, international economic regulations had been established by capitalism's center in its own favor. Developing countries, later called emerging countries, were at the most spectators at negotiation tables, and would certainly abide by the rules. All of this was seen as natural. After Cancún, in the view of Brazilian diplomacy, either the emerging countries would participate in the formulation of the rules or the process would stop. To create counterpower, this diplomacy worked then and thereafter to form coalitions in the South, the first of which was the G-20, a group of countries established on the occasion of the Cancún Conference to address trade issues.

The determination to democratize globalization added new facets to foreign policy: reinforcement of the role of the State as an international negotiator; sovereign defense of national interests, including big business under the process of being globalized; alliances with emerging countries with identical objectives, beginning with those of South America; open dialogue with, instead of subservience to more developed countries; and a component of morality in the form of fight against poverty and hunger. ${ }^{1}$

Lula has maintained the tradition of formulating and programming foreign policy as a State policy. It has preserved values, interests, and modes of conduct adopted through historical channels, such as an industrial calling and a harmonious connection between the State and society. It has preserved Brazil's historical participation in multilateral negotiation organizations and increased by more than thirty percent the number of countries where Brazil maintains diplomatic representations. It has established three external objectives: a) market liberalism ensuring reciprocity of benefits; b) expansion of business abroad through trade and internationalization of Brazilian companies; and c) reinforcement of military power to influence global order and sectoral regimes. This is what makes the logistic strategy of incorporation into the international scene.

1 BADIE, Bertrand. L'Impuissance de la puissance: essai sur les nouvelles relations internationales. Paris: Fayard, 2004. DUPAS, Gilberto. Atores e poderes na nova ordem mundial. São Paulo: Unesp, 2005. PAROLA, Alexandre G. L. A ordem injusta. Brasilia: FUNAG, 2007. 


\section{Consolidation of the logistic mode of participation in the international scene}

At the 2003 World Economic Forum in Davos, Lula, as an initial message of his first Administration, made clear his dissent from the neoliberal model, which he saw as an exaltation of the market-god. In the view of Foreign Minister Celso Amorim, blind faith in open markets and in the State's stepping back cannot induce development and equality among nations. The new leaders have thus developed an awareness of the role of the State and demanded political action to allow the country to penetrate global processes as an active agent in the system, without submitting itself to the play of traditional forces.

A logistic State is one that does not lend itself merely to rendering services, as was the case at the time of developmentalism, or to remaining a passive spectator of market forces and hegemonic power, as was the case at the time of neoliberalism. It is a logistic State because it reassumes development's strategic planning and the function of supporting and legitimizing the initiatives of other economic and social actors, to which it delegates responsibilities and power. Contrarily to literature's presumption about globalization, this new mode introduced by Cardoso and consolidated by Lula prevents governments from being incapable of governing owing to international forces. Being Brazil an organized society, with its class associations bringing together industrialists, farmers, bankers, workers, businessmen, and consumers, it is incumbent on the State to support the achievement of the interests of these segments of society, watching over the welfare of all, which is the supreme national interest. As all of this depends on both internal and external factors, the State ensures that the national interest has a weight on foreign policy, and becomes an agent of global governance. This development warrants seeing foreign policy in the Lula era as a decisive step toward maturity.

Two factors, among others, contribute to the consolidation of the logistic State in Brazil: the high degree of society's organization, which facilitates the leader's coordinating work; and political and economic stability, which prompts the linking of internal governability's logic to the logic of global governance. The combination of these factors, when placed at the service of development, gives rise to the logistic State, whose conduct differs from that of the neoliberal State, especially as it recovers the decision-making autonomy in the political sphere and turns to the reinforcement of national economy's hard core in the economic sphere.

In light of this conceptual framework, we can now review the different areas of external activity geared to the achievement of the nation's interests. And thereafter we can assess the results, as it is appropriate to a study of the country's international relations. ${ }^{2}$

2 CERVO, Amado Luiz. Inserção internacional: formação dos conceitos brasileiros. São Paulo: Saraiva, 2008. CARDOSO, José Celso (org). Desafios ao desenvolvimento brasileiro. Brasília: Ipea, 2009. BRASIL, Ministério das Relaçôes Exteriores. Política Externa Brasileira I. Brasília: FUNAG, 2007. Idem, DEP: Diplomacia, Estratégia e Politica. Brasília, MRE, n. 1, 2004. GUIMARÃES, Samuel Pinheiro. Desafios brasileiros na era dos gigantes. Rio de Janeiro: Contraponto, 2005. 


\section{High priority attached to integration into the global scene}

Brazil is forging ahead in the $21^{\text {st }}$ century to become a globalist country. But its mode of integration into the international scene differs from that of other globalist countries, such as Chile's. Chile's international insertion fits the tradeoriented globalism that prolongs society's infancy by taking as guidelines free trade treaties and an economy based on primary exports, i.e., neoliberal precepts of the 1990s. Brazil adopts the industrialist globalism mode, characterized at this stage of maturity of the development process by two essential features: reciprocal multilateralism and economic internationalization. We advance now to a more thorough study of these features to describe the Brazilian mode of incorporation into the international scene in the $21^{\text {st }}$ century.

\section{The concept of reciprocal multilateralism}

Brazilian foreign policy in the $21^{\text {st }}$ century operates through reciprocal multilateralism: "We want free trade, but free trade characterized by reciprocity," said Lula in Davos on January 26, 2003. Reciprocity does not apply only to international trade. In all areas of the international order - economy, trade, security, environment, health, and human rights - reciprocity is ensured when the rules of multilateral order benefit all nations. Without these rules, international order remains at the mercy of the stronger, as shown since 1945 by the discussions at GATT-WTO and the UN, the two pillars of multilateralism.

As a co-founder of these two more relevant multilateral organizations devoted primarily to trade and to security, respectively, Brazil has maintained continuity of ideas and conduct, as it has advocated the peaceful, negotiated solution of disputes and the promotion of the interests of the rich and the poor through the international trade system. However, multilateralism has not been guided by these principles over time. In the $21^{\text {st }}$ century, the Security Council still lacks representativeness, impartiality, and efficacy for maintaining peace, while the WTO lacks balance in the decision-making process to meet the nations' interests.

As of 2003, Brazilian foreign policy has found more power to demand reciprocity in international relations. "We have formed the G-20 in Cancun, when the United States and the European Union were attempting to impose an unfair agreement that left farm subsidies virtually untouched and offered little or no opening to products of interest to developing countries, while demanding from these disproportionate concessions," wrote Celso Amorim.

Brazilian diplomacy applies its concept of reciprocal multilateralism to trade and security, but also extends it to all areas of international relations. The concept involves two presuppositions: the existence of rules to govern the international order, without which the power disparity will prevail in favor of the great powers; and the joint formulation of these rules, so that they will not favor the interests of some to the detriment of the interests of others. 
Reciprocal multilateralism eliminates two theoretical utopias for an understanding of Brazilian foreign policy: hegemonic stability, and a necessary connection between foreign policy and political regime.

The hegemonic stability theory lies at the foundation of an international order based on the unilateral conduct of the dominating power - the United States since the end of the Cold War - or on the subservience of the others and the attendant irrelevance of the multilateral organizations. But a hegemonic instability theory would serve just as well as an explanation, according to Badie, as can be seen in contestation, anti-Americanism, terrorism, the outbreak of the financial crisis triggered at the hegemonic center, the random conduct of certain powers, the ease with which the States move. As hegemony does not engender order, much less an acceptable order, only multilateralism can preserve the order from the nations' selfishness, in the view of Brazil's foreign policy. In other words, the ideal order is the multilateral order.

A political regime does not necessarily show any connection with peace, development, justice, and mankind's welfare. Liberal and democratic regimes operate toward these ends but may also operate in an opposite direction. In South America, development models have shown similar results, regardless of the democratic or authoritarian nature of the different regimes. ${ }^{3}$

\section{Reciprocal multilateralism: examples}

To describe the reciprocal multilateralism that characterizes the Brazilian foreign policy in the $21^{\text {st }}$ century, we have chosen examples in five areas, for didactic purposes. (1) reciprocity in the international economy and in the decisions of the great economic powers: the G-8, whose meetings are attended by the Brazilian Head of State; and the financial G-20, whose first summit was held in November 2008 to combat the effects of the crisis and the stagnation of the developed countries; (2) international trade and Brazil's conduct at WTO's Doha Round, as well as its determination to establish coalitions among emerging countries; (3) international security, especially the efforts before the Security Council, and the valorization of the strategy of negotiation instead of that of violence in dealing with issues; (4) climate changes and other environmental issues; (5) health and human rights.

\section{International economy: G-8 and G-20}

The basic characteristic of Brazil's international economic relations is the pursuit of actual interdependence, i.e., of reciprocity in the achievement of interests through negotiation at different forums, and of economic internationalization.

3 BRASIL, Ministério das Relações Exteriores. Politica Externa Brasileira, I. Brasília: FUNAG, 2007. AMORIM, Celso. A diplomacia multilateral do Brasil. Brasília: FUNAG, 2007. 
Since 2003, negotiations have incorporated this economic policy and guided diplomacy's conduct at the WTO, in connection with the Free Trade Area of the Americas (FTAA), and toward the European Union, as well as in the formation of coalitions with emerging countries. The purpose of this strategy is to strengthen ties to the largest possible number of nations, blocs, and regions, regardless of their geographical situation, but with emphasis on the Southern Hemisphere, where Brazilian interests are more evident. In 2004, for instance, Argentina was the second largest destination of Brazilian exports, after the United States, while China came third, and southern countries were the destination of fifty percent of total exports. In 2010, China ranks as Brazil's first trade partner.

In economic relations with the European Union and the United States, the unrestricted liberalization of business, financial, and products flows does not serve the achievement of the national interest, as the country still lags behind them in productivity. With unrestricted liberalization, Brazil would jeopardize its industrial future. It is under this light that one should understand the rejection of free trade treaties, which perpetuate asymmetries; the search for partnerships and coalitions in the South; the attention to Mercosur; and the construction of South American economic unity - all of which are features of foreign policy's realism. While the North offers little other than a large market, and requires much in structural terms, relations with the South are more favorable, in addition to offering opportunities that would be insane on the part of good policy to miss.

The financial crisis that erupted in September 2007 in the United States and then spread to Europe, following the same pattern of capitalism's 1929 crisis, reveals the new equilibrium of the international economy, thus showing the appropriateness of Brazil's international economic policy, which maintains strong ties to the North, but reacts logistically to change. On the one hand, emerging countries appear, with good regulation, high productivity, production, and exports, in addition to holding huge amounts in United States Treasury papers; on the other, one sees bad regulation, high imports level, consumerism, low savings, and public indebtedness at the center of capitalism.

Rich countries hold frequent meetings to discuss the direction of international relations and their own interests, especially those that are not addressed by multilateral decisions of global organizations. For some years now, they have invited emerging countries they see as global actors to sit at the table. At the 2007 Germany Summit, for instance, the G-8 (Germany, Italy, France, United Kingdom, United States, Japan, and Russia) invited one of the G-5 (China, India, South Africa, Mexico, and Brazil), and offered President Lula the opportunity to attend the negotiations of the rich. At its $35^{\text {th }}$ Summit, held in Aquila, Italy, in July 2009, the G-8 decided to convert itself into the G-14 (G-8+G-5+Egypt). The invitation addressed at the G-5 was prompted not by mere courtesy but by these emergent countries' weight, needed for addressing the issues and solving problems on a global scale. 
When the developed economies went into recession in 2008, the G-8 was forced to dilute itself into the financial G-20, which shelters the twenty largest economies plus the European Union, a forum then established for adopting measures against speculation and for reigniting growth. But it is the rich countries' defense instinct that explains the maintenance of the G-8, which in June 2009 had been declared dead by Celso Amorim and; Lula, accordingly, characterized the same forum as inadequate to make decisions about the international economy. At the June 2010 Toronto meeting of the two forums, the G-8 reformulated its modus operandi.

As the instinct of defense, coupled with emerging interests and the multiplicity of economic negotiation forums (G-8, G-15, G-20, and Central Banks) fails to conciliate decisions, it entails the irrelevance of these multilateral meetings for conceiving the new economic order, to be ultimately determined by the rich and the emerging countries. The rich countries' economic stagnation reflects adversely on Brazilian economy in three ways: a reduction of exports, especially of manufactures, of foreign direct investment, and a slackening of the pace of economic growth. Reaction to these effects has been threefold: intensification of investments under the Growth Acceleration Program (PAC); reinforcement of the southern coalitions aimed at reforming the international financial system, the IMF, and the World Bank; and the making of ten billion dollars available to the IMF to reinforce its lending resources.

At economic forum meetings, Brazilian government has advocated biofuels as a means of meeting the energy challenge, which is similar to the challenge presented by China, with its massive population and its fast growth pace, to climate change. The investment protection issue, which puts in opposition the interests of two worlds, has been shifted to bilateral agreements. A new form of protectionism has come up into the discussion, introduced by countries such as Canada and the United States, which proclaim the freedom of investment but begin to reconsider and even prohibit businesses that might lead to the acquisition of their strategic corporations by emerging countries through shares transfer.

As regards intellectual property, which protects patents and technological innovation, discussion at the G-8 faces a similar situation. Regulations in favor of laboratories and corporations of rich countries are accepted with reservations by India and China, while Brazil has already issued compulsory licensing of medication against AIDS, thus breaking its patent.

From the negotiations with the big ones - if one might speak of real negotiation between rich and emerging countries - three conclusions can be drawn. First, the meetings address issues that are vital to Brazilian interests; the country should identify which regulations it would be advisable to accept and make its policy clear at multilateral forums and at the time of negotiating international agreements. Second, it is necessary to learn from this process, as the country now becomes a holder of intellectual property and international investor. Third, the 
perception imposes itself of how important it is for the national interest to preserve decision-making autonomy in foreign policy, as expressed in President Lula's unpolished words at the conclusion of the Germany meeting: "The developed world thinks that it can make a speech and that we have to take it as the last word and obey."'

\section{International trade and the WTO}

Globalization stimulates international trade in goods, services, and factors. The volume of foreign trade, exports and imports reflects on the income of producers and consumers, on the employment level, and on the country's external finances. Hence, attention should be devoted to trade.

After the trade deficit of the 1990s owing to the devaluation of the Real in 1999, Brazilian foreign trade showed an upward trend, but it was only as of 2003 that this rising trend confirmed itself, with considerable surpluses, owing to higher consumption and higher prices of export commodities. Finance Ministry data show that exports totaled 48 billion dollars in 1998, 60 billion in 2002, and 197.9 billion in 2008 , falling to 152.3 billion in 2009 , due to the crisis. Surpluses also arose, from minus one billion dollars in 1999 to 40 billion in 2007. This was the year when the list of exports was further diversified, including agribusiness exports, in which Brazil is a world leader (it ranks first as an exporter of ethanol, sugar, coffee, and orange juice), and sophisticated exports, such as aircraft and software. Manufactures, which accounted for 52.3 percent of the total, exceeded primary exports then. In 2007, the United States and the European Union accounted for less than half of Brazilian exports - 65 billion dollars as compared with 161 billion dollars. As consumption in rich countries fell, China became Brazil's first trade partner in 2010.

Despite globalization, the modernization of the Brazilian productive system, and the logistic strategy for integration into the international scene, Brazil has not been able in the $21^{\text {st }}$ century to substantially modify its list of exports and to reap greater benefits from foreign trade. In 2009 it exported more commodities than manufactures. As regards manufactures, 40 percent went to the major economies (United States, European Union, and China), while another 40 percent went to Latin America, which attests to the attention to the neighbor countries.

These data illustrate the Brazilian diplomacy's activism at the WTO. As an advocate of the liberalization of markets, Brazilian diplomacy seeks to address the imbalance between Brazilian productivity's higher status within the global system and its low participation in international trade. Two specific objectives drive Brazilian participation at these negotiations: to secure the liberalization of the

4 BATISTA JR. Paulo Nogueira. O Brasil e a economia internacional: recuperação e defesa da autonomia nacional. Rio de Janeiro: Elsevier, 2005. 
agricultural market and the end of farm subsidies in Europe and the United States; and refusal to make any concessions on manufacture trade as long as this injustice is not redressed. That is, to establish the reciprocity of trade benefits between the rich and the emerging countries. This Brazilian trade policy practiced also at the WTO governs all negotiations; and as it met with resistance, it caused the collapse of the FTAA and of the Mercosur-European Union Free Trade Agreement.

The trade G-20 was formed in Geneva, in August 2003, during preparatory meetings and thus preceded the Cancun Conference. It is made up of emerging countries willing to prevent the acceptance of results predetermined by the Northern powers at multilateral trade negotiations. Its original membership has been expanded from twenty to twenty-three member countries, whose ministerial meetings take place at regular intervals. The WTO has been taken by surprise by the upsurge of the emerging countries, which has caused it to change its modes of negotiation. It no longer accepts prior agreements between rich countries proposed to the Assembly as a possible consensus to be imposed from above. The interests of the South now make part of the negotiations' dynamics.

The two group's confrontation, particularly on the agricultural issue, dragged on for the entire decade, hampering negotiations, and confirming Celso Amorim's prediction that the WTO would tend to become irrelevant. On one side, stood the rich countries, which did not yield to the emerging countries' right to take part in the decision-making power which determines global trade order, demanding from them the liberalization of their industrial markets without giving up their farm policies; on the other side, stood the emerging countries, which since Cancún had gained sufficient power to do away with subservience in international relations and to ensure reciprocity in the achievement of interests. In June 2006, the Doha Round negotiations were suspended and were actually resumed only at the end of the decade. But discouragement took hold of diplomats and specialists. Agricultural negotiations were thus shifted to the United Nations, which convened a major FAO Assembly in 2008, in Rome, to discuss food security, which was placed in jeopardy by the food crisis. The meeting was attended by forty heads of state and 4,800 delegates from 192 UN member countries.

As it happened at the WTO, negotiations at FAO also bogged down and yielded insignificant results. In brief, at trade negotiations, countries easily shift responsibilities to one another.

For Brazil, multilateralism's failure at trade negotiations in the $21^{\text {st }}$ century both harms and disturbs political decisions in matters of foreign trade: should one continue to wager on global free trade, move toward the bilateralism of free trade as advised by diplomats of the Cardoso era and some businessmen, or seek an alternative in the South? As long as a change of strategy did not occur, the South alternative began to materialize. Trade with China now ranks first, South American integration has been promoted with this purpose in view, and in 
December 2009 Brazil signed a trade agreement with 22 developing countries, under which mutual tariffs have been reduced by 20 percent. $^{5}$

\section{Security and the Security Council}

The powers' security policy shows an internal face, the provision of means, and a strong connection with foreign policy. Despite multilateralism and the formation of blocs, security is grounded on internal reality, from where it draws the means for action and for exercising the decision-making power. In recent years, the Brazilian academia has involved some groups in the study of security issues, which are no longer limited to a concern on the part of the armed forces and of diplomacy. According to Vaz, there is a gap in Brazil between the strategic capability and the perception of the role to be played at the regional and global levels.

With its ability to form consensuses, Brazilian diplomacy offsets the armed forces' scarce means of dissuasion and defense. This is why it extols Brazil's international role in security matters. It berates the United States's unilateral preemptive action, the doctrine of European intervention and terrorism; in addition, it to links security to development and to the combat of hunger. It proposes a strategy of favoring negotiation over the resort to violence for the solution of conflicts and the maintenance of peace. It points out the positive effects of its praxis on the construction of peace and calls for the democratization of decisions at the Security Council as another way of achieving reciprocity in the multilateral order. It has recently taken initiatives in this respect, such as the attempted mediation between Iran and the West in regard to that country's nuclear program; also in the talks between Arabs and Israelis regarding conflicts in the Middle East. But Brazilian diplomacy has not been successful in its attempt to join the exclusive club of political and military power, which remains firmly closed.

The 1996 plan to reform national defense led to institutional advances, such as the establishment of the Ministry of Defense and the alternation of civilian ministers at its whelm, which however produced no effect on the country's strategic capability. Ten years later, the Lula government drafted a second plan conceptually appropriate for reequipping the armed forces but whose results are not yet known: to restart the military industry and technological research aimed at providing the armed forces with internal means. But as long as a cultural change does not occur in the country, foreign policy will remain deprived of operational means.

Despite these contradictions, Brazilian foreign policy moves on with the intention of playing a relevant role in the field of security, based on the negotiated conflict solution. In 2004, Brazil joined Southern Cone countries,

5 BRASIL Ministério das Relações Exteriores. O G-20 e a OMC: textos, comunicados e documentos. Brasília: FUNAG, 2007. Idem, Resenha de Politica Exterior do Brasil, n. 83, 2003. See "Informe sobre o Comércio Mundial 2008 - O comércio em um mundo em processo de globalização,” prepared by the WTO. 
Argentina and Chile, secured the cooperation of Uruguay, Peru, and Bolivia, assumed the command of the troops, and acted to bring peace, development, and redemocratization to Haiti - Brazil's major involvement in UN peace missions since 1946.

Let us now look at two objectives of Brazilian external involvement: the UN Security Council and the South American Defense Council.

Consistently with its pacifist foreign policy, Brazil has preference for a multilateral approach as a mechanism for solving conflicts. It attaches importance to the UN Security Council, of which it has made part since its founding, and frequently participates in peace missions. But Brazil calls for a reform of the Council in view of its lack of representativeness and of effectiveness in facing $21^{\text {st }}$ century conflicts.

In 2005, the Brazilian government submitted to the UN General Assembly a proposal for the Council's reform, a proposal that had the support of other members of the G-4 (Brazil, India, Germany, and Japan), a group of major powers that wish to be made permanent members of the Council. Despite the G-4 endeavors, global reaction prevented the reform. The five permanent members' fear of losing power, the regional rivalries among powers, and disagreement as to the nature of the reform have kept the Council just as it was when it was established right after World War II.

On the occasion of the signing of the treaty establishing the Union of South American Nations (Unasur) in Brasilia in 2008, the Brazilian government submitted a proposal for the establishment of a South American Defense Council as one of Unasur steering bodies. After some obstacles to its establishment were overcome, the Defense Council was officially established in March 2009. Its purpose is to keep external powers away from security matters in South America, to maintain the region as a zone of peace and negotiation, and to solve any regional conflicts.

Threats to security in Brazil's neighborhood do not come from the reequipment of the nations' armed forces, ideological differences between governments, of geopolitical rivalries. But the United States's reactivation of the IV Fleet, which operates in Latin America, Central America, and the Caribbean, inactive since 1950, and the use of seven airbases ceded by Colombia are a regional hegemonic power's answer to South America's pretended security autonomy. ${ }^{6}$

6 VAZ, Alcides Costa. La agenda de seguridad de Brasil: de la afirmación soberana hacia la cooperación. In: Cepik, Marco e Socorro, Ramírez (orgs.). Agenda de Seguridad Andino-Brasileña. Bogotá: Fescol, 2004, p. 145174. PAGLIARI, Graciela De Conti. O Brasil e a segurança na América do Sul. Curitiba: Juruá, 2009. BRASIL, Ministério das Relaçôes Exteriores. Política Externa Brasileira, II. Brasília: FUNAG, 2007. Idem, Resenha de Politica Exterior do Brasil, n. 96, 2005. ALSINA Jr. João Paulo Soares. Politica externa e política de defesa no Brasil: síntese imperfeita. Brasília: Câmara dos Deputados, 2006. 


\section{Climate and other environmental issues}

In the view of the Brazilian foreign policy, the environmental issue encompasses three other issues: the planet's survival; development; and hunger. Multilateral negotiations for establishing appropriate regimes to address these issues have always been carried out under the auspices of the United Nations. Three Conferences were devoted to the matter: Stockholm in 1972; Rio de Janeiro in 1992; and Johannesburg in 2002. Brazilian diplomacy has played a significant role in this area, with the intention of introducing the reciprocity of effects into the discussion.

The industrial countries introduced the environmental issue into multilateralism at the Stockholm Conference; thereafter, the developing countries injected their interests into the discussion, and in this Brazil has had a prominent role, as it has always associated the issue with development, and more recently with sustainable development.

The discussion has turned into polemics. On one side, the rich countries ascribe poverty and hunger to causes located in the South, such as corruption, government incompetence, and the restricted opening to the economic agents of capitalism's center. Since Rio-1992 they have been willing to finance projects of their interest. On the other side are developing countries, who point to the industrial countries as the culprits of environmental degradation and of the inequality among nations. Though hampered, the discussion has proceeded, with conceptual gains for the developing countries, but with scant actual effects in general.

Climate change has become the most salient issue in the discussion. It surfaced in 1992, was the subject of a convention that entered into force in 1994, made headway after the 1997 Kyoto Protocol, in force since 2005, and has attracted public attention owing to the reports of the Intergovernmental Panel on Climate Change, released by the United Nations since 1990.

International law sets targets for pollutant gas emissions that cause the planet's warming; these targets are compulsory for the industrial countries and left to the emerging countries' sense of responsibility. Alleging that compulsoriness interferes with its sovereignty, the United States has refused to ratify the Kyoto Protocol, thus setting up a serious obstacle to the regime's success ten years after it was established. Moreover, the Copenhagen Conference failed.

Under these circumstances, the United Nations is going ahead with its efforts to save the planet from the climatic scourges that compromise not only the planet's very survival but also the survival of the poor. In late 2007, the XIII United Nations Climate Change Conference was held in Bali, Indonesia, and was attended by 189 countries. Totally isolated, the United States gave in and finally a protocol of intentions for the post-Kyoto era was signed, to enter into force in 2012. The regime was supposed to make progress as the emerging countries 
committed themselves to reduce their emissions with the help of technologies financed by the rich countries, including the United States, which would then make quantified cuts. ${ }^{7}$ But the truth is there has been no progress. This is the conclusion warranted by the failure of the 2009 Copenhagen Conference, the $15^{\text {th }}$ conference of parties on climate change, which was attended by heads of state and fifteen thousand delegates.

\section{Health and human rights}

Military spending and the costs financial systems' recovery after the recent crisis have required huge sums, particularly in the developed countries. The internal and international impact has been indifference toward hunger, the internal difficulties of many nations, and the heightening of international tension. Mankind's food situation became more serious in 2007-08.

The Brazilian foreign policy regarding human rights, as in the aforementioned cases, is critical of an international order devoid of reciprocity or justice. Human rights have been seen traditionally by the North in light of the ideas inherent to the liberal revolutions of the $18^{\text {th }}$ century, which were incorporated into the United Nations 1948 declaration. Since World War II, this strain of political philosophy has inspired the realism of international relations theory and of political praxis, which vests the States with hegemony for defining the global order on the basis of interests and power, or rather, on the basis of the interests of those that wield power, without taking morals into consideration. This realism, a target of criticism in the North as well, does not match the Brazilian vision, which for decades has associated human rights with development and, in the Lula era, with combating poverty and hunger.

At the UN General Assemblies he has attended since 2003 and at meetings of world leaders and of multilateral organizations, President Lula or his diplomats have chastised an order that ignores the scourge of hunger and disease, thereby violating human rights. On the domestic front, action is taken through social programs such as the Family Grant, the driving engine of the Zero Hunger subprogram; on the external front, action is taken through cooperation extended to poorer countries, especially from Africa. Before Lula, the Brazilian government already resorted to international negotiations in this area, and achieved results, such as the Trade-Related Aspects of Intellectual Property Rights-TRIPS mechanism adopted by the WTO, under pressure from the emerging countries, so as to rein in the right to medical drugs patents and expand the use of these medicines when required by public health. As an example, it may be mentioned that in 2007 , the Lula government, frustrated over the lack of results in the negotiations with a

7 LAGO, André Aranha Corrêa do. Estocolmo, Rio, Joanesburgo: o Brasil e as três conferências ambientais das Naçōes Unidas. Brasília: FUNAG, 2007. 
lab holding the rights to the Efavirenz, a drug for combating AIDS, ordered the competent agency to break its patent. ${ }^{8}$

\section{Internationalization of the Brazilian economy}

For the first time in history, internationalization of Brazilian companies has become part of the country's external strategy. Lula indicated this conceptual change at the 2005 Davos World Economic Forum when he said: "Something I have repeatedly said to Brazilian businessmen is that they should not be afraid to make their companies into multinationals, to make investments in other countries, as this would be very good for Brazil.” At meetings with businessmen, Celso Amorim, has reaffirmed the objective of turning Brazil into a globalized country, through the expansion of its businesses abroad. "Brazil has exchanged a participation in the international scene through dependence and subordination for a sovereign, cooperative participation...," said the President that same year before hundreds of businessmen in São Paulo. The dialogue between Lula and the business community will continue.

A trend that has deserved much attention in international relations since 1990, globalization manifests itself in two ways: access to markets and expansion of internal businesses abroad and of external businesses into the internal domain. Europe and the United States have benefited from globalization and thereby increased their systemic competitiveness since the end of the Cold War. Brazil's objective in this regard is to have strong corporations to compete on a global scale, with the State's logistic support and the financial support of national institutions, such as the National Economic and Social Development Bank (BNDES) and the Bank of Brazil. If Cardoso privatized [enterprises], Lula conglomerated [them]. The President's finger is behind the formation of the great national conglomerates. Despite this earlier achievement, Brazil has a long way to go before attaining the density of developed countries, whose multinationals co-opt their own governments, which then form coalitions and use pressure to influence decisions at multilateral organizations, such as the WTO, the IMF, and the World Bank, and for the signing of bilateral treaties, and ultimately to obtain internal and intergovernmental rules in their own favor.

The Brazilian businesses' rising globalization trend has been recorded by the Brazilian Society of Studies on Transnational Corporations and Economic Globalization, whose data we have used here.

The internationalization of the Brazilian economy has picked up speed since 2005, in tandem with the trend in the emerging countries. Brazilian direct investments abroad have increased an average of 14 percent a year, rising from

8 CORREA, Luiz Felipe de Seixas (org.). O Brasil nas Naçôes Unidas: 1946-2006. Brasília: FUNAG, 2007. PAROLA, op. cit. 
6.4 billion dollars in 2004 to 18 billion dollars in 2006, but falling to 13.9 billion dollars in 2008 and dropping to 4.5 billion dollars in 2009 owing to the global financial crisis. The emerging countries held about 5 percent of direct investments abroad in 1990 but this percentage exceeded 20 percent by 2007. In that year, with 180 billion dollars consolidated, Brazil had become the second foreign investor among the emerging countries and foreign investments in Brazil totaled 34.6 billion dollars, a 100 -percent increase over the previous year. In early 2008 , international reserves totaled 194 billion dollars, a threefold increase over the previous two years (59.8 billion dollars), and continued to rise, exceeding 250 billion dollars in 2010, after the country received the investment grade from the risk rating agencies. In December 2008, Brazil's consolidated direct investment abroad totaled 149 billion dollars.

Brazilian corporations invest abroad, starting in South America, where they maintain about one thousand companies, showing that the movement involves medium companies as well as large groups. Among the major ones, Vale do Rio Doce and Petrobras lead the way, followed by Gerdau, Embraer, Odebrecht, Itaú, Braskem, Votorantim, Camargo Correia, and WED, and others. They operate in various areas, including mining, prospecting, metallurgy, industry, and technology. Because of the legislation in neighbor countries, investments have been redirected: between 2001 and 2008, investments in Argentina fell from 15 percent to 9 percent; between 2001 and 2010, the share of investments in the United States, which became the main investments destination, rose from 13 percent to 37 percent of Brazil's total direct investments abroad.

The companies' motivation varies: a valued currency, which prompts the acquisition of shares in multinationals; the establishing of subsidiaries; the association with or the purchase of other companies, which facilitates the raising of financial resources abroad; technological development; and raising productivity to a systemic global level, in addition to stimulus to higher quality exports. Globalization occurs also when a company enters production chains in a worldwide network. By failing to follow this trend, national economy perpetuates its structural dependence. As a remarkable example of this gain in maturity, one often refers to Embraer, whose performance has been studied by Martinez.

After its 1994 privatization, anchored on the technological knowledge amassed by two previous centers - the Brazilian Aeronautics Center and the Aeronautics Technological Institute - the Brazilian Aeronautic CorporationEMBRAER turned to global market, adopted new innovation processes, replenished its resources, and embraced specialization for competing. Years later, it ranks as third maker of commuter jets in the world, and its products have topped the list of Brazilian exports.

The central countries are showing signs of concern over the pace and the effects of the internationalization of businesses from emerging countries and are starting a dangerous tendency to reverse globalization. Substantial financial stock 
is being accumulated in the treasury of emerging countries that are exporters of raw materials or manufactures, such as the Arab countries and China. These countries establish sovereign funds, which currently total about three trillion dollars, of which 250 billion in possession of the Brazilian treasury.

The reversal of the financial situation now under way still does not displace the hegemony of the capital of developed countries, but is leading these countries to resort to other forms of protectionism, such as raising difficulties to or barring transfer of the control of the assets of their multinationals to emerging countries, arguing that control of their multinationals determine their structural position on the capitalist system's hierarchy.

Before seeking developed markets, Brazilian capital was channeled primarily to South America, especially to Argentina, where today it is part of Quilmes, in the brewery area; of Perez Companc, in the fuel and energy sector; of Loma Negra, the cement concern; of Alpargatas, in textile and footwear; and of Acindar, the steel company; in addition to major export packinghouses.

\section{Integration and bilateralism: establishment of the global network}

The formation of blocs is the trend in international relations in the $21^{\text {st }}$ century, although it lacks the dynamics of the 1990s. The European Union has given up on a Constitution, rejected through plebiscites in 2005, and replaced it with the Lisbon Treaty, which has also failed to obtain unanimous approval of the 27 members. In South America, governments endeavor to improve social and economic conditions, which had deteriorated at the time of neoliberalism, and seek domestic solutions, based on national projects, in addition to programming different modes of participation in the international scene. Here also, some governments do not view integration as an efficient strategy for overcoming difficulties. Under these circumstances, the Brazilian foreign policy, of a marked integrationist bent, makes use of integration processes to establish or consolidate the cooperation and power network directed at the South, starting from South America and advancing toward alliances with other regions, so as to achieve the goal of making Brazil into a global-oriented country.

\section{Mercosur and Unasur}

The concept of relations along the same axis has been introduced into the international relations theory on the basis of a study by Patrício, who investigated the role played in the origin and development of integration processes by bilateral relations between key countries in a region, such as France and Germany in the

9 BRASIL, Ministério das Relações Exteriores. Politica Externa Brasileira, II. Brasília: FUNAG, 2007. Idem, Resenha de Política Exterior do Brasil, n. 96 e 97, 2005. SARFATI, Gilberto. Carta Internacional, USP, out. 2007. MARTINEZ, Maria Regina Estevez. A globalização da indústria. 
case of the European Union, and Brazil and Argentina in the case of MERCOSUR and South America. We have presented this concept and reviewed its application to the South American case in my book Inserção Internacional.

Brazil-Argentina relations were affected by the 1999 devaluation of the Real, the Brazilian currency, and even more seriously by Argentina's profound economic and social crisis in 2001-2002. At the outset of the $21^{\text {st }}$ century, the governments of Néstor Kirchner and of Luiz Inácio da Silva faced a trade dispute caused by Brazilian export manufactures that hindered Argentine industrialization. Other factors helped raise further difficulties in the management of bilateral relations and their impact on neighbor countries: scarce provision of energy, the acquisition of Argentine debt bonds by the Venezuelan government, and the approval of Venezuela's adhesion to MERCOSUR by Uruguay and Argentina and obstruction on the part of the Brazilian and the Paraguayan Congresses for some years. As regards multilateral negotiations, the two countries have been in tune because they have identical interests. The same has occurred in regard to regional security on the occasion of the crisis between Colombia and Ecuador in March 2008, triggered by a preemptive action by Colombia against a guerrilla camp located on Ecuadoran territory. In brief, the axis has survived, the partners walking side by side though not hand in hand.

In addition to the exponential growth of Brazilian direct investments in Argentina, bilateral trade has also been favorable to Brazil. Between 1996 and 2003, Argentina recorded yearly surpluses of nearly one billion dollars, equivalent to a little over 10 percent of total bilateral trade. Between 2004 and 2007, as a reflection of the Argentine crisis, it was Brazil's turn to record surpluses that rose from 1.8 billion to 4.0 billion dollars. Significantly, manufactures account for nearly all Brazilian exports, less than 30 percent of Argentina's. This difference in the exports list is an indication of unequal development.

Succeeding her husband as President of the Republic in 2008, Cristina Fernández de Kirchner expressed willingness to reestablish good understanding with Brazil, as Argentina had shown to be capable of economic recovery. Attention was then given to deepening integration in the areas of energy, science and technology, defense, production, space, and nuclear matters. This past February, the two countries signed seventeen bilateral agreements covering these areas, an indication that both see relations along an axis as being essential.

The first South American countries summit meeting, held in Brasilia in 2000, reflected the intent of furthering regional integration, with Mercosur as a starting point. An action plan for the integration of regional infrastructure (IIRSA) was then established. The 2004 summit meeting of the 12 countries in Ouro Preto, Minas Gerais, took steps in this direction, establishing funds to finance economic convergence and the organization of a future community of South American nations. The Mercosur Parliament, with its headquarters in Montevideo, later replaced the Interparliamentary Commission. As a matter of 
fact, Mercosur decisions mingled with South American decisions, showing the desired intertwining of the two integration processes.

Brazilian foreign policy sees Mercosur as a political project that neoliberalism's crisis and the continued existence of asymmetries have made more flexible. Organized segments of Brazilian society intended to use it in favor of their business transactions, while diplomacy envisages it as an instrument for reinforcing the international bargaining power. All things considered, integration purports to establish a regional hub more appropriate for achieving the objectives of multilateral reciprocity and of globalization of the Brazilian economy. At bottom, just as in all countries and sectors of international relations, the hegemony of national interests comes first, more so in the $21^{\text {st }}$ century than in the 1990 s.

The building up of South America advanced, consistently with Brazilian political thinking, with the announcement of the Community of South American Nations at the 2004 Cuzco Summit, which was established on the Margarita Island in 2007, but became institutionally enacted under the Union of South American Nations-Unasur constitutive treaty signed on May 24, 2008 at the summit of the twelve South American countries in Brasilia.

On the basis of its operational structure and purposes, one could say that Unasur does not play only a mediating role between Brazilian interests and foreign policy's global objectives. If it becomes operational, the recently created nucleus of power- the entity South America - will fully meet Brazilian interests.

The Union is structured into four bodies: The Council of Heads of State, the Council of Foreign Ministers, the South American Defense Council, and the Council of Delegates.

Unasur came into being to serve political, geopolitical, and economic objectives. In the political area, when the Member States unanimously approve decisions, their intention is to put the region on the world map, express the unison voice of the countries in a multilateral setting, and enhance its political independence, as it enjoys the status of a legal entity under international law. In the geopolitical area, although it is not a military alliance, it creates a regional nucleus of power and ascribes emphasis to regional security; disputes in this context are settled through diplomatic activity, on the basis of South American international law doctrines, respect of sovereignty, and nonintervention in the internal affairs of the States. This precludes the intervention of external powers and organizations, such as the OAS, the Rio Group, and the old Inter-American Treaty of Reciprocal Assistance signed at the outset of the Cold War. In the economic area, Unasur seeks to promote production, energy, and infrastructure integration, but without replacing either Mercosur or the Andean Community, both of which remain active.

This South American integration process displays two distinctive characteristics: originality as compared with other experiences and the fact that it starts with political and geopolitical rather than economic integration, as was the case of the European Union. 
Doubts raised at the time of Unasur's founding regarding its performance questioned the possibility of excessive bureaucracy, the superimposition of regional bodies, the scarceness of financial resources, and the difficulty - given the cult of sovereignty and political arrogance - of implementing projects aimed at improving infrastructure and at energy integration. One finds in South America a variety of models of international integration, and different worldviews and concepts of regional integration. Nevertheless, favorable conditions warrant this new step forward in the process of integration: economic growth early in the century and greater social inclusion, in addition to the establishment of financial reserves and the availability of energy stocks. ${ }^{10}$

\section{Casting the net beyond the neighborhood}

The casting of a global network as a goal of Brazilian foreign policy in the $21^{\text {st }}$ century gains impetus with reciprocity multilateralism impelled by diplomacy, which establishes coalitions and takes the leadership in global negotiations, and with economic internationalization, impelled by Lula's personal interest and by economic and social agents. The net weaves its first threads in South America in these two aspects and, fortified at its base, extends toward the world, as if this were Brazil's natural locus. We should now look at this long-reach movement and the ties to blocs, regions, and countries beyond South America.

\section{Blocs and regions}

Relations between Europe and Brazil take place in three contexts: relations between the European Union and Mercosur; relations between the European Union and Brazil; and relations between European countries and Brazil. Since 1995 negotiations have been under way for establishing a European Union-Mercosur free trade area; but though fifteen years have elapsed, no conclusion has been reached. The impasse is due to the Brazilian aversion to treaties that do not include reciprocity, as is the case here and with the treaty calling for the establishment of the Free Trade Area of the Americas (FTAA), which has never been concluded either. Europeans and Americans do not relinquish their agricultural subsidies and protectionism but demand concessions in the areas of industrial goods, public call to bids, and services, which would place Brazil's industrial development at risk.

However, recognizing Brazil's role in the international economy and in multilateral negotiations, especially in the conclusion of WTO's Doha Round and of the Mercosur-EU agreement, the European Union, at a special summit meeting

10 PATRÍCIO, Raquel C. de C., As relaçōes em eixo franco-alemãs e as relaçôes em eixo argentino-brasileiras: génese dos processos de integração. Lisboa, ISCSP, 2007. CERVO, Amado Luiz. Relações internacionais da América Latina: velhos e novos paradigmas. São Paulo: Saraiva, 2007. COUTO, Leandro Freitas. O horizonte regional do Brasil: integração e construção da América do Sul. Curitiba: Juruá, 2009. SARAIVA, Miriam Gomes. As estratégias de cooperação Sul-Sul nos marcos da política externa brasileira de 1993 a 2007. Revista Brasileira de Politica Internacional, n. 50 (2), 42-49, 2007. 
held in 2007, proposed to confer on Brazil the status of a "strategic partner", a proposal that was endorsed by the European Parliament. In the European view, Brazil, as a key country in the region, is an indispensable ally in meeting global challenges related to climate change, human rights, intellectual property, industrial policy, and other economic and social issues. The European decision was based on specific data and on expectations: Brazil accounts for approximately 80 percent of Mercosur's GDP; while the European Union accounts for 22 percent of the Brazilian foreign trade, it directs only 1.8 percent of its foreign trade to Brazil. European investments in Brazil are significant, but business would increase should there be a better regulatory framework and lower customs duties - if adopted, these measures would facilitate European Union's relations with South America.

This concession to Brazil signals a change in the European bloc's international strategy; since its formation, the bloc had assigned priority to inter-bloc relations, assuming that it would export its model of integration that yielded recognized benefits. Brazil became European Union's eighth strategic partner, after the United States, Japan, Canada, India, Russia, China, and South Africa. The programming of the joint cooperation plan began promptly and has continued at ministerial meetings and at a series of Brazil-European Union summits held since then.

The financial crisis affected the European Union, disclosing some countries' heavy public indebtedness, triggering recession, and threatening the Euro. Trade with and investments in Brazil were indirectly affected. A further difficulty in recent bilateral relations has been raised by Brazilian diplomacy's strong reaction to the EU's collective measures and police action to contain and discipline immigration. This reaction was especially strong in view of the detention and mistreatment of about 2,500 Brazilian tourists at the Madrid airport in 2008 and the mistaken execution of Brazilian Jean Charles at the London subway. All these, as Itamaraty officially pointed out, meant disregard for human rights.

Bringing together potentially great economies, Brazil took the initiative of forming a political bloc of emerging countries, which was formally established in 2007, under the acronym BRIC - Brazil, Russia, India, and China. The bloc purports not only to promote business transactions among its members by also to coordinate their diplomatic activity and adopt common stances in respect of issues of their interest in international negotiations. Its weight on the international scene has rapidly increased owing to the accelerated growth of the four economies and to the recession that has affected the rich countries. As was the Brazilian diplomacy's desire, from now on multipolarity is a fact, so that the establishment of rules for the global order has now to mean shared responsibility.

Since the first BRIC foreign ministers meeting in Yekaterinburg, Russia, in May 2008, there have been other meetings of foreign ministers as well as of other authorities. In 2009 summit meetings of the four great emerging countries have been held on a regular basis, the first of which also in Yekaterinburg and the second in Brasilia in 2010. The bloc is gaining life and now has influence on the 
establishment of the rules that govern the global order by the financial G-20, the IMF and World Bank policies, the United Nations reform, the Doha Round and the legal frameworks in important areas of international relations. World power is thus acquiring a new face, with BRIC being on the same footing as the old G-8.

IBAS is another political group devoted to cooperation among its members and to the harmonization of positions vis-à-vis the international scene. It came into being in Brasilia in 2003, bringing together three major southern countries inclined to make autonomous decisions - each one being the major democracy on its respective continent: India, Brazil, and South Africa. Other than global interests that occupy the group in their successive summit meetings, such as associating social inclusion and development, South-South cooperation is envisaged under agreements covering areas of specific needs, such as trade, security, information technology, energy, health, food, and interconnection with Mercosur.

The emerging countries have given indication of their strength at the joint BRIC-IBAS summit meeting held in Brasilia in April 2010, when international economy was facing the worst crisis since the Great Depression of the 1930s and at a time when global governance is at a crossroads, facing the challenge of promoting sustainable development.

In May 2008, Lula attended the summit meeting of the member countries of the Central American Integration System (SICA) held in El Salvador, to reinforce economic, political, and cultural relations with one more regional bloc, one that unites eight countries of Central America. The command of the United Nations Stabilization Mission in Haiti (MINUSTAH), successfully carried out with concern for economic and social issues, has opened the doors of the Caribbean to Brazil. Not only Haiti but also other countries in the region are receiving attention from the Brazilian government, which provides logistic support for business transactions and investments, especially for oil prospecting and the production of biofuels. The new interest in the region, previously removed from Brazil and close to the United States, was illustrated by the Brazilian diplomacy's disastrous involvement when the Honduran Judiciary and Executive deposed President Manuel Zelaya in 2009, accused of threatening to subvert the Constitution.

The net extends also to Africa and the Arab countries. Lula has visited Africa more than a dozen times, in addition to helping bringing about the African Countries-Latin America summit meeting and being a special guest at the African Union Summit. Positive results from this approximation include programs in the area of health, especially for combating AIDS, credit lines, the presence of Brazilian contractors, activity by Petrobras, integration with Mercosur, increased exports, and a common stance against farm subsidies. Although economic and strategic returns from relations with the Community of Portuguese-Speaking Countries (CPLP) are scant, cultural gains are substantial. Africa is creating favorable conditions for foreign presence, and in this respect the United States, China, and Brazil stand out. 
Since 2003, the government intended to change the Brazilian policy toward the Near East and the Arab countries and even to establish an Arab-Latin American bloc so that the two regions could raise their voices at international negotiations and Brazil could expand its trade with the Muslim world. This thought led to the South America-Arab Countries Summit held in Brasilia in May 2005, a new example of Brazilian diplomacy's activism. The summit was attended by 33 countries - 11 from Latin America and 22 from the Arab world, including the six members of the Gulf Cooperation Council - and 800 businessmen. The summit elicited no concern on the part of the powers used to intervening in the region Europe and the United States - given the Brazilian diplomacy's moderating role worldwide. The same cannot be said of the agreement signed by Brazil. Turkey, and Iran aimed at making possible the Iranian nuclear program. On the occasion, Secretary of State Hilary Clinton voiced the indignation of the United States's conservative sector against the Brazilian diplomacy's naïve intervention in an area where western powers have been traditionally involved.

\section{Bilateralism}

Bilateral relations or relations between a given country and a bloc have intensified in the $21^{\text {st }}$ century for three main reasons: first, the crisis of multilateralism, as illustrated by the United Nations inefficiency and its stagnated reform, and the WTO'S incapacity to conclude the Doha Round; secondly, the State's reinforcement after neoliberalism's failure, especially in Latin America, and the United States's unilateralism; thirdly, the proliferation of bilateral free trade agreements - the new trade policy carried out outside the WTO.

Bilateral free trade agreements have stricken a fatal blow against negotiations of a global agreement at the WTO. Brazilian diplomacy abhors the former as much as it prefers the latter. By 2007, a network of approximately 400 of these bilateral agreements had been signed, encouraged by the United States, eventually joined by the European Union, particularly in Asia and in Latin America.

Relations between Brazil and the United States unfold in a dual context: on the one hand, the foundation provided by a historical political and economic alliance between the two countries, whose benefits have always been perceived and appreciated by both parties, regardless of which governments are in office; on the other hand, competition between the two, both as regards geopolitical views and the confrontation of specific economic interests. This substratum conditioned bilateral relations under the two Administrations of George W. Bush and Luiz Inácio Lula da Silva in the first decade of the $21^{\text {st }}$ century. The two leaders talked with each other with frankness and autonomy, whether in agreement or disagreement.

Used, just as their predecessors, to consulting with businessmen of their respective countries, Bush, Lula, and Barak Obama have had little to do to help 
them move forward on their own and discover business opportunities on the other side, as the way has been opened decades ago. But the presidents of the two countries have established on their own a special partnership under the technological cooperation agreement signed in Camp David in March 2007, on the production and marketing of ethanol and other biofuels. In addition, the two governments have signed a military cooperation agreement in April 2010, without compromising sovereignty. And through negotiations, they have solved bilateral disputes, such as the one caused by WTO's authorization for Brazil to retaliate against the United States because of cotton subsidies.

Relations between Brazil and China, viewed as strategic by both governments view as strategic, are based on the principles of mutual trust, bilateral trade, and coordination of positions in respect of multilateral policies, pursuant the communiqués issued by $\mathrm{Hu}$ Jintao and Luiz Inácio Lula da Silva, the two presidents, as they exchanged visits in 2004 and 2010. Relations are closely followed by the Brazil-China Businessmen Council. Studies sponsored by this Council have shown that Brazil has progressed from being an exporter of commodities to being a destination of Chinese investments and that since 2009 China ranks first as Brazil's trading partner. During Jintao's last visit, a wide-ranging Joint Action Plan was established.

The strong effort to establish a partnership springs from the familiarity cultivated at multilateral forums, such as the conferences on the environment, the financial G-20, and BRIC, and finds bilateral expression in trade and investments. Imports of capital goods, raw materials, and intermediary goods have facilitated the expansion of the Brazilian industry, while the imports of final consumer goods have fallen to approximately 10 percent. The trend of business transactions attenuates the pressure of Brazilian industrialists on the government to contain the entry of Chinese manufactures, such as footwear, plastics, and textiles, as well as Itamaraty's complaint because of the lack of Chinese investments in Brazil. On the other hand, Brazilian investments in China are scarce and restricted to the area of technological cooperation between Brazil's National Space Research and the Chinese Space Agency, which in 2007 launched jointly a remote sensing satellite.

Brazil and India take common positions at multilateral forums, especially aimed at changing trade rules to their benefit, but their bilateral cooperation is meager and IBAS does not fill this gap. Despite good political and geopolitical understanding, as illustrated by BRIC's very existence, another country that maintains bilateral relations with Brazil much below the potential is Russia, as regards both trade and technological cooperation. There persists in Brazilian diplomacy a utopian presumption of a possible transfer of military technology by other countries, such as Russia, France, China, and the United States. This presumption became evident in the attempts made by Defense Minister Nelson Jobim, all of which frustrated, as it is natural to expect in this area of international relations. 
To celebrate the first centennial of Japanese immigration, Japan's Crown Prince visited Brazil in 2008. On that occasion, an assessment was made of our historical bilateral relations, comparable to those established with the United States, if one considers the participation of Japanese companies in Brazil's industrialization process in recent decades. Brazilian agribusiness exports to Japan also enhance these relations, recently intensified by cooperation in the area of biofuels production and marketing. The challenges to be met for strengthening these relations further call for the expansion of bilateral trade, still modest, and for higher Japanese investments, which have remained stagnant in recent years and kept Brazil as a seventh destination.

As regards Europe, in addition to maintaining traditional relations, the Lula government has renewed the nuclear agreement with Germany and now welcomes France's renewed interest in our country. Portugal and Spain are the $21^{\text {st }}$ century newcomers, as our bilateral relations shifted from the sentimental to the instrumental plane. As dynamic agents of economic internationalization, the two Iberian countries have turned their attention to Brazil, which they have chosen as their preferential partner in Latin America for both economic and cultural reasons. Around 2000, Brazil became the first destination of Portuguese and Spanish direct investments abroad, which have been channeled in Brazil to both large and medium enterprises. As privatizations have ceased, just as has the establishment of great corporations, particularly in the area of communications, these flows will tend to abate.

In South America, despite the formation of blocs, relations privilege the bilateral trend, such as in energy integration projects, for instance. On the occasion of Argentina's bicentennial celebration, two books edited by Botana and Russel have compiled excellent analyses of the internal and external profile of that country, Brazil's main partner. They also explain in depth the concepts of declinacion and of international extravio, as well as Brazil's success and difficulty in dealing with Argentina. Countries with a strong introspective bias, such as Venezuela, Bolivia, Ecuador, and Paraguay do not disturb Lula's good humor, and he maintains spontaneity in his relations with their leaders.

From the preceding and on the basis of other cases not mentioned, one concludes that in the world of globalization all attention should be devoted to bilateralism, the crucial path for ensuring the achievement of national interests. This is a tempting stance, as multilateralism and integration are two waning trends, while the unfettered movement of national States seems to be the rising tendency. ${ }^{11}$

Received July $1^{\text {st }}, 2010$ Accepted November 11, 2010

11 LIMA, Maria Regina Soares de \& Hirst, Monica (orgs.). Brasil, India e Africa do Sul: desafios e oportunidades para novas parcerias. São Paulo: Paz e Terra, 2009. OLIVERIA, Henrique Altemani (org.). China e Índia na América Latina. Curitiba: Juruá, 2009. COSTA, Carla Guapo da. A cultura como factor dinamizador da 


\section{Abstract}

Since Cardoso and during Lula's Administration, the international order has undergone significant changes. These changes have allowed the Brazilian foreign policy to mitigate internal effects of an order established by others and, at the same time, to become an active participant in the formulation of the new order. To democratize globalization became the mainspring of Brazilian foreign policy. In the scope, President Lula has maintained the tradition of formulating and programming foreign policy as a State policy, and also has fostered the logistic strategy of incorporation of Brazil into the international scene.

\section{Resumo}

Do governo Cardoso ao governo Lula, a ordem internacional passou por significativas mudanças. Essas mudanças permitiram a política externa brasileira mitigar os efeitos interno da ordem estabelecida pelos outros ao mesmo tempo em que participa ativamente na formulação de uma nova ordem. Democratizar a globalização tornou-se motivação da política externa brasileira. Nesse escopo, o Presidente Lula manteve a tradição de formular e programar a política externa brasileira como política de Estado, mas também aprofundou a estratégia logística de inserção do Brasil no cenário internacional.

Key-words: Brazilian foreign policy; new global order; emerging countries.

Palavras-chave: política externa brasileira; nova ordem global; potências emergentes.

economia: os investimentos portugueses no Brasil. Lisboa: UTL, 2005. PINO, Bruno Ayllón. As relações BrasilEspanha na perspectiva da política externa brasileira (1945-2005. São Paulo: Emblema, 2006. RUSSELL, Roberto (org.). Argentina 1910-2010: balance del siglo. Buenos Aires: Taurus, 2010. BOTANA, Natalio R. (org.). Argentina 2010: entre la frustración y la esperanza. Buenos Aires: Taurus, 2010. Principais sites utilizados: Ministério das Relações Exteriores, Universidade de Brasília (Mundorama, Cena Internacional), Universidade de São Paulo (Carta Internacional, Contato), Instituto de Pesquisa do Rio de Janeiro (Observatório Político SulAmericano), Conselho Empresarial Brasil-China, Sociedade Brasileira de Estudos de Empresas Transnacionais e da Globalização Econômica, Instituto Argentino para el Desarrollo Económico, Centro Argentino de Estudios Internacionales, Centro Latinoamericano de Administración para el Desarollo. 